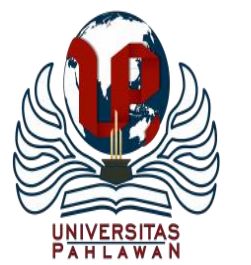

Edukatif : Jurnal Ilmu Pendidikan Volume 3 Nomor 5 Tahun 2021 Halm 2847 - 2853

EDUKATIF: JURNAL ILMU PENDIDIKAN

Research \& Learning in Education

https:/ledukatif.org/index.php/edukatif/index

\title{
Pengaruh Pola Asuh Orangtua terhadap Kemandirian Anak Usia 5-6 Tahun di Perumahan Militer PUSKESAD
}

\author{
Nur Rama Dini Sa'adah ${ }^{1 凶}$, Khusniyati Masykuroh ${ }^{2}$ \\ Universitas Muhammdiyah Prof. Dr. Hamka, Indonesia ${ }^{1,2}$

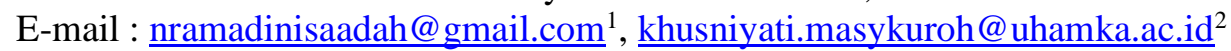

\begin{abstract}
Abstrak
Sikap mandiri merupakan bagian dari perilaku anak yang harus dikembangkan sejak dini sebagai pondasi keterampilan kehidupan kelak. Kajian penelitian ini bertujuan untuk melihat pengaruh pola asuh orangtua terhadap kemandirian anak untuk usia 5-6 tahun di perumahan Pusat Kesehatan Angkatan Darat Jakarta (PUSKESAD). Penelitian ini menggunakan metode pendekatan kuantitatif dengan mengambil sampel menurut kriteria khusus dengan melakukan survey kepada 36 orangtua penghuni perumahan PUSKESAD yang berprofesi di bidang militer. Hasil analisis data menunjukkan bahwa pola asuh otoriter dan demokratis yang dilakukan oleh orangtua di perumahan militer PUSKESAD menunjukkan persentase yang hampir sama, yaitu $50 \%$ dan $44 \%$. Sedangkan $6 \%$ orangtua di perumahan militer PUSKESAD melakukan pengasuhan dengan pola permisif. Hasil uji hipotesis menunjukkan nilai t hitung sebesar $-0,025$ lebih rendah dari t table 2,068 dan nilai signifikan 0,01 lebih kecil dari 0.05 sehingga dikatakan pola asuh orangtua tidak mempengaruhi anak usia 5-6 tahun di perumahan militer PUSKESAD. Penelitian bisa dilanjutkan untuk mengetahui kemungkinan factor-faktor lain yang dapat mempengaruhi kemandirian anak seperti kelekatan aman anak dengan ibu, pola pembiasan rutinitas sehari- hari di rumah, regulasi diri dan kedisiplinan.
\end{abstract}

Kata Kunci: Pola Asuh, Kemandirian, Anak Usia Dini.

Abstract

An independent attitude is part of a child's behavior that must be developed from an early age as the foundation of life skills later. This research study aims to see the effect of parenting on the independence of children aged 5-6 years in the Jakarta Army Health Center housing (PUSKESAD). This study uses a quantitative approach method by taking samples according to specific criteria by conducting a survey to 36 parents of residents of PUSKESAD housing who work in the military field. The results of data analysis showed that the authoritarian and democratic parenting styled by parents in PUSKESAD Housing showed almost the same percentage, namely 50\% and 44\%. Meanwhile, $6 \%$ of parents in PUSKESAD housing provide care with a permissive pattern. The results of the hypothesis test show that the t-count value is -0.025 lower than the t-table 2.068 and the significant value is 0.01 less than 0.05, so it is said that parenting does not affect children aged 5-6 years in the PUSKESAD military housing. Research can be continued to determine the possibility of other factors that can affect children's independence such as the child's secure attachment to the mother, the pattern of refraction of daily routines at home, self-regulation and discipline.

Keywords: Parenting, Independence, Early Childhood

Copyright (c) 2021 Nur Rama Dini Sa'adah, Khusniyati Masykuroh

$\triangle$ Corresponding author

Email : nramadinisaadah@gmail.com

DOI : https://doi.org/10.31004/edukatif.v3i5.1010

ISSN 2656-8063 (Media Cetak)

ISSN 2656-8071 (Media Online) 
2848 Pengaruh Pola Asuh Orangtua terhadap Kemandirian Anak Usia 5-6 di Perumahan Militer PUSKESADNur Rama Dini Sa'adah, Khusniyati Masykuroh

DOI : https://doi.org/10.31004/edukatif.v3i5.1010

\section{PENDAHULUAN}

Usia dini merupakan waktu yang tepat untuk mengembangkan segala aspek perkembangan karena anak mengalami proses tumbuh dan berkembang secara pesat. Masa ini merupakan waktu yang tepat untuk mengembangkan semua aspek perkembangan termasuk kemandirian pada anak. Kemandirian merupakan suatu kemampuan mengatur dan mengerjakan kegiatan atau tugas sehari- hari tanpa bantuan orang lain (Desi Ranita Sari, 2019; Haeriah, 2018; Riska Fitriana Sulistyowati Mariani, 2019) Anak yang mandiri dalam arti lain, anak belajar untuk memenuhi kebutuhannya sendiri seperti membersihkan tubuh, memakai pakaian, tanpa bantuan orang lain. Anak yang mandiri dapat bersosialisasi dengan mudah dengan lingkungannya sendangkan yang jiwa kurang mandiri jiwa sosialnya rendah dan selalu bergantung kepada orang tuanya (Safitri \& Aini, 2018). Sikap mandiri bagian dari potensi anak dalam berperilaku yang harus dikembangkan untuk memudahkan kehidupan anak kelak. Kemampuan tersebut dapat dilatih dengan cara memberikan pembiasaan, orang tua memberikan kepercayaan dan komunikasi pada anak, dan akan mereka bawa sampai dewasa. Kemandirian anak dibentuk melakui proses dan tahapannya sesuai usia dan berkembangnya anak, serta bagaimana anak mendapatkan pengasuhan dalam keluarganya. Anak akan tumbuh dengan percaya diri, mandiri, dan mempunyai sikap sosial yang baik saat mendapatkan pengasuhan penuh kasih sayang, diterima, didukung, dan dihargai oleh orangtua (Utami, 2018).

Pola asuh orang tua adalah sikap yang di berikan orang tua dalam pengasuhan berupa memelihara, melindungi, mendidik dan mengarahkan kehidupan anak dari bayi hingga dewasa (Bestari Wardiyaningsih, Muniroh Munawar, 2017; Muhadi, 2015; Sugiyati, 2018). Bentuk- bentuk pola asuh dibedakan menjadi tiga yaitu: otoriter dimana orang tua menerapkan aturan ketat, komunikasi satu arah dan berfokus pada hukuman (fisik atau verbal); demokratis dimana orangtua mendidik anak dengan komunikasi dua arah, memberikan apresiasi atau hukuman terhadap yang dilakukan anak; dan permisif dimana orang tua dengan kecenderungan membebaskan anak (Asri, 2018).

Empat aspek pola asuh yaitu kepercayaan, kebiasaan, komunikasi, kedisiplinan, dan disiplin diyakini akan membantu proses terbentuknya kemandirian pada anak (Desi Ranita Sari, 2019). Ciri- ciri kemandirian ditunjukkan dengan : 1) Tanggung Jawab, menyelesaikan tugas atau pekerjaannya sampai selesai; 2) Indenpendesi, tidak bergantung kepada orang lain; 3) Otonomi dan Kebebasan, mampu mengendalikan dan mempengaruhi apa yang terjadi pada dirinya; 4) Berani, dapat mengambil keputusan atas dirinya sendiri; 5) Rasa Ingin Tahu, memiliki ketertarikan akan suatu hal (Fitri, 2018) . Ciri- ciri anak usia 5-6 Tahun yaitu anak aktif saat melakukan kegiatan, dapat berinteraksi dengan teman,percaya diri di lingkungannya, dapat berkomunikasi dengan baik, mampu berfikir secara logis dan dapat mengekspresikan dirinya (Safitri \& Aini, 2018).

Karakteristik kemandirian ditunjukkan melalui kemandirian emosional saat anak dapat mengendalikan emosinya terhadap orang tua dan lingkungan sekitar; kemandirian tingkah laku saat anak dapat mengambil keputusan tanpa bantuan orang lain, dan kemandirian nilai saat anak dapat mengetahui suatu nilai sikap salah dan benar (Hewi, 2015). Seorang anak penting untuk memiliki sifat mandiri supaya bertanggungjawab terhadap apa yang dilakukan dan menjadi pribadi yang tidak bergantung pada pihak lain (Harahap et al., 2021). Segala hal yang dibiasakan oleh orangtua akan mudah ditirukan oleh anak, apakah itu hal yang baik atau buruk termasuk kemandirian (Jaya, 2021). Faktor yang mempengaruhi kemandirian antara lain pola asuh, jenis kelamin, dan urutan anak dalam keluarga (Hurlock, 2011). Bagaimana cara orangtua mengasuh dalam kehidupan sehari-hari, membiasakan anak dalam menyelesaikan tugas pribadi, akan mempengaruhi tingkat kemandirian anak. Urutan anak dalam keluarga, anak pertama yang diharapkan sebagai contoh dan menjaga adiknya diharapkan lebih mandiri dan urutan dalam keluarga memengaruhi mandirinya anak sesuai yang digunakan. 
Pola asuh yang dilakukan setiap orang tua berbeda dan lingkungan terdekat anak dibesarkan akan mempengaruhi pertumbuhan dan perkembangan anak. Budaya yang berlaku di tempat anak tinggal, lingkungan dan teman bermain juga mempengaruhi kemandirian anak. Dalam penelitian ini, peneliti tertarik untuk melihat pengaruh pola asuh keluarga militer yang ada di perumahan Pusat Kesehatan Angkatan Darat (PUSKESAD), Jakarta. Berdasarkan studi pendahuluan melalui wawancara dengan ketua Posyandu Perumahan PUSKESAD menjelaskan bahwa semua penghuni perumahan adalah anggota militer yang terbiasa dalam penerapan disiplin pada aturan termasuk dalam kehidupan sehari-hari. Orang tua yang berlatar belakang militer di lingkungan pekerjaannya mempunyai jiwa disiplin yang kuat dan dapat menerapkan nilai- nilai moral dalam mendidik anaknya. Anak-anak sudah terbiasa untuk ditinggal ayah atau ibu yang bekerja di PUSKESAD sesuai dengan jam kerja, bahkan tugas menginap ke luar kota dalam jangka waktu tertentu. Namun peneliti menemukan beberapa anak usia 5-6 tahun di Perumahan PUSKESAD belum menujukkan kemandirian sesuai tahapan usianya, antara lain dengan belum bisa makan mandiri dan masih harus disuapi, tidak tuntas menyelesaikan kegiatan, dan sering meminta bantuan orang lain dalam menyelesaikan tugas pribadinya.

Penelitian mengenai pola asuh di lingkup keluarga militer pernah dilakukan pada lingkungan keluarga Polisi Republik Indonesia (POLRI) Riau Pekanbaru yang menunjukkan hasil bahwa pola asuh yang digunakan orangtua adalah demokratis dan berdampak anak mempunyai hubungan sosial yang baik dengan menunjukkan kesopanan kepada orang yang lebih tua, saling menyapa ketika bertemu, dan tersenyum kepada orang lain yang menyapa (Sundari, 2016). Penelitian lain dilakukan pada keluarga yang bertempat tinggal di Asrama Polisi Toddopuli Kota Makassar menunjukkan bahwa pola asuh orangtua adalah pola asuh campuran dan situasional dengan menggabungkan pola otoriter, permisf, dan demokratis, serta membawa dampak positif dan negatif terhadap kepribadian anak serta kemampuan sosial anak (Nur \& Abdullah, 2020). Pada studi ini, peneliti akan meneliti tentang pengaruh pola asuh orangtua terhadap kemandirian anak di perumahan militer PUSKESAD Jakarta.

\section{METODE PENELITIAN}

Penelitian ini menggunakan pendekatan kuantitatif dengan menggunakan purposive sampling untuk mengambil sample dengan kriteria khusus yaitu orangtua yang tinggal di perumahan militer PUSKESAD dan memiliki anak usia 5-6 tahu. Desain penelitian kuantitatif yang peneliti gunakan berupa penelitian survei dimana data dikumpulkan secara sistematis dari suatu populasi dan sampelnya melalui beberapa bentuk atau permintaan langsung. Populasi penelitian ini adalah anak berusia 5-6 tahun di perumahan militer PUSKESAD dengan jumlah 55 anak, sedangkan sampel yang diambil 36 orang. Data penelitian ini merupakan data primer yang didapatkan langsung dari beberapa responden dengan cara menyebarkan angket atau kuesioner. Kuesioner ini diberikan dan diisi secara langsung di lapangan, responden diminta untuk mengisi item pertanyaan dengan cara memilih salah satu jawaban "Ya tau Tidak". Kuesioner ini telah diberikan dan isi dengan sampel sebanyak 36 orang tua di perumahan militer PUSKESAD. Teknik analisis data menggunakan beberapa pengujian yang menjadi pemenuhan, Uji Normalitas, Uji Homogenitas, Uji Linieritas dan dengan cara Uji hipotesis untuk mengetahui hasil apakah Ha diterima atau Ho ditolak, Penghitungan dan uji data dilakukan dengan menggunakan bantuan aplikasi SPSS 20 for Windows

\section{HASIL DAN PEMBAHASAN PENELITIAN}

Tabel 1. Distribusi Responden Gaya Pola Asuh Orangtua di Perumahan PUSKESAD

\begin{tabular}{ccc}
\hline Pola Asuh & Jumlah (orang) & Persen (\%) \\
\hline Otoriter & 18 & 50 \\
\hline
\end{tabular}


2850 Pengaruh Pola Asuh Orangtua terhadap Kemandirian Anak Usia 5-6 di Perumahan Militer PUSKESADNur Rama Dini Sa'adah, Khusniyati Masykuroh

DOI : https://doi.org/10.31004/edukatif.v3i5.1010

\begin{tabular}{ccc}
\hline Demokratis & 16 & 44 \\
\hline Permisif & 2 & 6 \\
\hline & 36 & 100 \\
\hline
\end{tabular}

Hasil analisis pada tabel 1 menunjukkan bahwa pola asuh otoriter dan demokratis yang dilakukan oleh orangtua di Perumahan PUSKESAD menunjukkan persentase yang hampir sama, yaitu $50 \%$ dan $44 \%$. Sedangkan 6\% orangtua di Perumahan PUSKESAD melakukan pengasuhan dengan pola permisif.

Analisis data dilakukan untuk menguji hipotesis penelitian. Untuk uji validasi dan uji realibilitas pada instrument dinyatakan valid. Uji Normalitas dilakukan untuk melihat populasi dan pendistribusiannya.

Tabel 2. Uji Normalitas Deskriptive

\begin{tabular}{llll}
\hline & $\begin{array}{l}\text { Descriptiv } \\
\text { Statistic }\end{array}$ & \\
\hline & N & & Skewness \\
\hline & Statistic & Statistic & Std. Error \\
\hline Keman & & & \\
dirian & 36 & -741 & .393 \\
Pola & 36 & 574 & .393 \\
Asuh & & & \\
\hline
\end{tabular}

Berdasarkan tabel 2, hasil uji normalitas dengan melihat nilai Skewness dibagi nilai error of skewness dari masing - masing variable. Variabel kemandirian menunjukkan kontribusi normal dengan nilai sebanyak 1,8 dan variabel pola asuh orang tua menunjukkan data berkontribusi normal dengan memperoleh nilai sebanyak 1,4 dimana nilai tersebut masih pada rentang -2 sampai dengan 2.

Berikutnya dilakukan Uji Homogenitas untuk melihat apakah data bersifat homogen ataupun tidak.

Tabel 3. Uji Homogenitas

\begin{tabular}{lccc} 
Kemandirian & \multicolumn{3}{l}{} \\
\cline { 2 - 4 } & df & F & Sig. \\
\hline $\begin{array}{l}\text { Between } \\
\text { Grroup }\end{array}$ & 7 & 964 & .476 \\
\hline
\end{tabular}

Berdasarkan perhitungan Uji Homogenitas pada tabel 3 di atas.,ditemukan hasil dari nilai Sig. adalah 0,476 menunjukkan angka yang lebih besar dari $\alpha=0,05$. Dapat diambil kesimpulan karena 0,476> $\alpha=0,05$ maka data dikatakan homogen.

Selanjutnya adalah Uji Linieritas. Penelitian ini menguji linearitas dengan menggunakan analisis varians (Anova), dengan kriteria jika nilai signifikan lebih besar dari 0,05 maka hubungan variabel $\mathrm{X}$ dan $\mathrm{Y}$ linier, sebaliknya jika nilai signifikan lebih kecil dari 0,05 maka hubungan variabel $\mathrm{X}$ dan $\mathrm{Y}$ tidak linier.

Tabel 4. Uji Linieritas

\begin{tabular}{lcc}
\hline & \multicolumn{2}{l}{ ANOVA Table } \\
\cline { 2 - 3 } & $\mathrm{F}$ & Sig. \\
\hline $\begin{array}{l}\text { Deviation From } \\
\text { Linearity }\end{array}$ & 1.125 & .374 \\
\hline
\end{tabular}

Tabel Deviation from Linearity menunjukkan hasil 0,374 lebih besar dari 0,05 maka dikatakan data penelitian ini bersifat linear.

Langkah selanjutnya adalah melakukan Uji Hipotesis untuk melihat kebenaran hipotesis penelitian yang telah dibuat apakah hipotesis diterima atau ditolak. Ho adalah tidak adanya pengaruh antara pola asuh orang 
2851 Pengaruh Pola Asuh Orangtua terhadap Kemandirian Anak Usia 5-6 di Perumahan Militer PUSKESAD-

Nur Rama Dini Sa'adah, Khusniyati Masykuroh

DOI : https://doi.org/10.31004/edukatif.v3i5.1010

tua di Perumahan PUSKSAD terhadap kemandirian anak, sedangkan hasil $H a$ adalah terdapat pengaruh pola asuh orangtua di Perumahan PUSKESAD terhadap kemandirian anak.

Uji regresi liniear sederhana dilakukan dengan menggunakan aplikasi SPSS 20 for Windows dan mendapatkan hasil :

Tabel 5. Uji Regresi Liniear Sederhana

\begin{tabular}{lccccc}
\hline & \multicolumn{5}{c}{ Coefficients } \\
\cline { 2 - 7 } & \multicolumn{2}{c}{$\begin{array}{c}\text { Unstandardized } \\
\text { coefficients }\end{array}$} & $\begin{array}{c}\text { Standardized } \\
\text { Coefficients }\end{array}$ & $\mathrm{t}$ & Sig. \\
\hline Model & $\mathrm{B}$ & Std.Error & Beta & & \\
\hline 1. (Constant) & 15.259 & 1.535 & & 9.94 & .000 \\
Pola Asuh & & & & 1 & \\
& -.006 & .220 & -004 & -.025 & .001
\end{tabular}

a. Dependent Variable : Kemandirian

Hasil analisis pengaruh pola asuh orang tua terhadap kemandirian anak pada Tabel 5 di atas menunjukkan nilai hasil $t$ hitung dengan hasil -0,025 dinyatakan lebih rendah dari pada t table 2,068 dan nilai signifikan 0,01 hasilnya lebih kecil dari 0.05 sehingga $H o$ diterima dan $H a$ ditolak,. Karena Ho diterima maka tidak terdapat adanya pengaruh pola asuh orang tua terhadap kemandirian anak untuk usia 5-6 tahun di perumahan militer PUSKESAD. Hal ini sejalan dengan penelitian yang dilakukan pada orangtua di Kecamatan Alalak Banjarmasin yang menunjukkan tidak ada pengaruh pola asuh orang tua terhadap kemandirian anak (Baiti, 2020) dan juga penelitian yang dilakukan pada orangtua dan anak SD Negeri 38 Kota Parepare yang menunjukkan bahwa pola asuh tidak membawa pengaruh terhadap kemandirian anak (Pratiwi, 2020). Penelitian sejenis yang dilakukan Rina Mariani pada anak di Sekolah Luar Biasa Negeri Suka maju Simpang Propau Kabupaten Lampung Utara menunjukkan hasil tidak terdapat adanya hubungan antara pola asuh dan kemandirian anak, sehingga kemandirian anak tidak di pengaruhi pola asuh orang tua (Rina Mariani, 2016) penelitian yang dilaksanakan Jacomina di TK Kuntum Ceria Ambon pada tahun 2019 juga memberikan hasil tidak adanya korelasi pola asuh dan mandiri pada anak (Salakory, Kariyadi, \& Bumbungan, 2005).

Penelitian ini mempunyai keterbatasan karena hanya meneliti variabel pola asuh saja sebagai faktor yang mempengaruhi atau tidak terhadap kemandirian anak. Terdapat kemungkinan penyebab lain yang mempengaruhi kemandirian anak di Perumahan militer PUSKESAD seperti hasil penelitian yang dilakukan pada orangtua dan anak kelompok B TK PKK Banaran Kabupaten Ponorogi yang menunjukkan hasil penelitian kelekatan aman anak dengan ibu berpengaruh terhadap tingkat kemandirian anak (Amin, Kristiana, \& Fadlillah, 2021). Penyebab lain yang mungkin mempengaruhi kemandirian anak ditunjukkan dari hasil penelitian yang dilakukan di PAUD Kecamatan Gunung Kencana Lebak Banten bahwa kemandirian dipengaruhi oleh pola pembiasaan rutinitas sehari-hari anak di rumah (Karmila \& Khosiah, 2020). Penelitian lain yang dilakukan di SD Negeri Sebomenggalan, SD Negeri Kepatihan Purworejo, dan SD Negeri 2 Baledono, Kecamatan Purworejo, Kabupaten Purworejo juga menunjukkan hasil bahwa kemandirian anak dipengaruhi oleh regulasi diri dan kedisiplinan. Dengan demikian, untuk mengetahui mengenai faktor apa yang mempengaruhi kemandirian anak di perumahan militer PUSKESAD bisa dilakukan penelitian lanjutan dengan memperhatikan faktor-faktor di atas.

\section{KESIMPULAN}

Hasil penelitian memperlihatkan pola asuh orangtua di perumahan militer PUSKESAD tidak mempunyai pengaruh pada kemandirian anak. Penelitian bisa dilanjutkan untuk mengetahui kemungkinan 
2852 Pengaruh Pola Asuh Orangtua terhadap Kemandirian Anak Usia 5-6 di Perumahan Militer PUSKESADNur Rama Dini Sa'adah, Khusniyati Masykuroh

DOI : https://doi.org/10.31004/edukatif.v3i5.1010

faktor lain yang mempengaruhi kemandirian anak seperti kelekatan aman anak dengan ibu, pola pembiasaan rutinitas sehari-hari di rumah, regulasi diri, dan kedisiplinan.

\section{DAFTAR PUSTAKA}

Amin, M., Kristiana, D., \& Fadlillah, M. (2021). Jurnal Pendidikan Anak Usia Dini Pengaruh Kelekatan Aman Anak Pada Ibu Terhadap Kemandirian Anak Usia 5-6 Tahun Abstrak. Jurnal Obsesi, 5(1), 127134. Https://Doi.Org/10.31004/Obsesi.V5i1.504

Asri, I. G. A. A. S. (2018). Hubungan Pola Asuh Terhadap Perkembangan Anak Usia Dini. Jurnal Ilmiah Sekolah Dasar, 2(1), 1-9.

Baiti, N. (2020). Pengaruh Pendidikan, Pekerjaan, Dan Pola Asuh Terhadap Kemandirian Anak. Jurnal Edukasi Anak Usia Dini, 6(1), 44-57. Https://Doi.Org/10.18592/Jea.V6i1.3590

Salakory, J. A., Kariyadi, \& Bumbungan, A. (2005). Hubungan Pola Asuh Ibu Dengan Kemandirian Anak Usia Pra Sekolah Di Taman Kanak-Kanak Kuntum Ceria Ambon. Jurnla Kesehatan Terpadu (Itegrated Helath Journal), 27(1), 166-169.

Bestari Wardiyaningsih, Muniroh Munawar, M. K. (2017). Perbedaan Kemandirian Anak Ditinjau Dari Pola Asuh Orang Tua: Studi Komparatif Pada Anak Kelompok A RA Al Iman Ungaran. 140-157.

Desi Ranita Sari, A. Z. R. (2019). Peran Orang Tua Pada Kemandirian Anak Usia Dini. Jurnal Pendidikan : Early Childhood, 3(1), 1-12.

Fitri, I. (2018). Peningkatan Kemandirian Anak Melalui Pembelajaran Practical Life Di TK Annisa.

Haeriah, B. (2018). Pengaruh Pola Asuh Orang Tua Terhadap Kemandirian Anak Kelompok B Taman KanakKanak PGRI Gerunung Tahun Pelajaran 2017/2018. Jurnal Ilmiah Mandala Education, 4(1), 184-188.

Harahap, H. S., Hrp, N. A., Nasution, I. B., Harahap, A., Harahap, A., \& Harahap, A. (2021). Hubungan Motivasi Berprestasi, Minat Dan Perhatian Orang Tua Terhadap Kemandirian Siswa. Eduakatif: Jurnal Imu Pendidikan, 3(4), 1133-1143.

Hewi, L. (2015). Kemandirian Usia Dini Di Suku Bajo (Studi Kasus Pada Anak Usia 4-6 Tahun Di KB Nur' Ain Mola Selatan Kabupaten Wakatobi Provinsi Sulawesi Tenggara Tahun 2015). JPUD - Jurnal Pendidikan Usia Dini UNJ, 9(2). Https://Doi.Org/Https://Doi.Org/10.21009/JPUD.091.05

Hurlock, E. B. (2011). Psikologi Perkembangan. Erlangga.

Jaya, I. (2021). Analisis Metode Bercerita Menggunakan Boneka Tangan Dalam Meningkatkan Kemampuan Berhitung Anak Usia 5-6 Tahun. Edukatif: Jurnal Ilmu Pendidikan, 3(1), 84-91.

Karmila, R., \& Khosiah, S. (2020). Pengaruh Rutinitas Di Rumah Terhadap Kemandirian Anak. Jurnal Pendidikan Luar Sekolah, 14(1), 20-25. Https://Doi.Org/10.32832/Jpls.V14i1.3348

Muhadi, A. I. (2015). Hubungan Pola Asuh Demokratis Terhadap Kemandirian Anak Di Taman Kanak Kanak El-Hijaa Tambak Sari Surabaya. Jurnal Pendidikan Islam, 4(1).

Nur, H., \& Abdullah, A. (2020). Pola Asuh Dalam Keluarga Polri Di Asrama Polisi Toddopuli Kota Makassar. Phinisi Integration Review, 4(1), 73-83.

Pratiwi, K. E. (2020). The Influence Of Parents On Children' S Independence In Primary School 38 State Parepare City. Jurnal Ilmiaj Manusia Dan Kesehatan, 1(1).

Rina Mariani. (2016). Mental Di Sekolah Luar Biasa Negeri Sukamaju Simpang Propau Kabupaten Lampung Utara. 9(1), 37-42.

Riska Fitriana Sulistyowati Mariani, S. (2019). Hubungan Pola Asuh Orang Tua Dengan Kemandirian Anak Usia 4-6 Tahun Di RA. Raudatul Jannah Sei Miai Dalam Banjarmasin. Wiraraja Medika: Jurnal Kesehatan, 9(2), 58-62. 
2853 Pengaruh Pola Asuh Orangtua terhadap Kemandirian Anak Usia 5-6 di Perumahan Militer PUSKESADNur Rama Dini Sa'adah, Khusniyati Masykuroh

DOI : https://doi.org/10.31004/edukatif.v3i5.1010

Safitri, N., \& Aini, W. (2018). Gambaran Penanaman Kemandirian Dalam Keluarga. Jurnal Pendidikan Luar Sekolah, 1(1), 85. Https://Doi.Org/10.24036/Spektrumpls.V1i1.9005

Sugiyati. (2018). Hubungan Pola Asuh Orang Tua Dengan Kemandirian Sosial Anak Usia 4-5 Tahun Di PAUD Islam Kecamatan Sungai Raya.

Sundari, K. D. (2016). Pola Asuh Anak Dalam Lingkungan Keluarga POLRI (Studi Dia Asrama Polda Riau Pekanbaru). Jurnal Ilmu Komunikasi, 3(2), 1-15.

Utami, K. (2018). Hubungan Pola Asuh Orang Tua Terhadap Kemandirian Anak Usia Pra Sekolah Di TK Negeri Pembina Lombok Barat 2017. 103-114. 